\title{
Literasi Informasi Digital : Sebuah Tantangan Bagi Pustakawan
}

\author{
Daryono \\ UPT Perpustakaan Universitas Bengkulu \\ e-mail: daryono@unib.ac.id
}

\begin{abstract}
Information literacy, in addition to being seen as a set of interpersonal competencies, can also be understood from the standpoint of society and human rights. The creativity of librarians in developing and improving services in the digital age is needed to pay attention. Librarians are able to take an active role in taking part in today's emerging technology era by innovating in services. In this era of technology and digital become the trend with slogan "world in our grip" so that library can no longer only build physical facilities and services which are conventional ones, but they have to be developed according to the development of time. Any intensive communication with users is an attempt to find out how digital information literacy is used and how library information literacy services can be integrated to the digital lifestyle of the users. In the world of librarianship the facts mentioned above are more appropriate if they are viewed in the context of digital information literacy that have been parts of the program in many libraries. However, it is necessary to extend the scope considering that digital phenomena are basically related to the use of media and communal capital in everyday life.
\end{abstract}

Key Words: Information Literacy, Digital Literacy, Librarian

\section{Abstrak}

Literasi informasi selain dipandang sebagai sekumpulan kompetensi interpersonal dapat juga dipahami dari sudut pandang kemasyarakatan dan hak asasi manusia. Kreativitas pustakawan dalam mengembangkan dan meningkatkan layanan di era digital sangat perlu diperhatikan. Pustakawan mampu berperan aktif mengambil bagian dalam era teknologi yang berkembang saat ini dengan melakukan inovasi dalam layanan. Pada era teknologi dan digital ini menjadi trend dengan slogan "dunia dalam genggaman" sehingga perpustakaan tidak dapat lagi hanya membangun fisik maupun layanan yang bersifat konvensional, tetapi harus mengembangkan diri sesuai dengan perkembangan zaman. Komunikasi intensif dengan pemustaka adalah upaya untuk mengetahui bagaimana literasi informasi digital yang digunakan dan bagaimana layanan literasi informasi 
perpustakaan dapat terintegrasi dengan gaya hidup digital pemustaka. Dalam dunia kepustakawanan kenyataan-kenyataan tersebut di atas memang lebih tepat jika dilihat dalam konteks literasi informasi digital yang selama ini sudah menjadi bagian dari program di banyak perpustakaan. Namun diperlukan perluasan cakupan mengingat fenomena digital pada dasarnya berkaitan dengan penggunaan media dan modal komunkasi dalam kehidupan sehari-hari.

Kata Kunci : Literasi informasi, Literasi digital, Pustakawan

\section{Pendahuluan}

Perpustakaan merupakan institusi dimana berbagai macam sumber informasi dikelola kemudian dapat dimanfaatkan oleh para pemustaka harus mampu memahami dan tanggap terhadap perkembangan ilmu pengetahuan dan informasi. Demikian halnya dengan perpustakaan perguruan tinggi dimana kebutuhan para pemustaka terhadap informasi jauh lebih tinggi dan lebih bervariasi dibanding dengan tingkat pendidikan di bawahnya, karena di perguruan tinggi mengemban program Tri Dharma perguruan tinggi, disinalah peran pustakawan perguruan tingi harus mampu menangkap sinyal kebutuhan informasi pemustaka di era digital native ini.

Kreatifitas dan kompetensi pustakawan dalam mmengembangkan dan meningkatkan layanan di era digital perlu diperhatikan. Pustakawan harus mampu berperan aktif mengambil bagian, mengidentifikasi kebutuhan pada pemustaka di era teknologi yang berkembang saat ini. Apabila pustakawan tidak melakukan inovasi dalam layanan maka akan menjadi tertinggal dan dampaknya pada perpustakaan sebagai sumber informasi dan tempat menyeberkan ilmu pengetahuan hanya sebagai slogan saja.

Pustakawan harus menjalin komunikasi intensif dengan pemustaka untuk mengetahui dengan bagaimana poka literasi informasi mereka. Pola literasi informasi pemustaka perlu diketahui dengan baik oleh pustakawan sehingga kemampuan dalam melakukan, mencari, memilih dan menemukan informasi menjadi suatu keahlian tersendiri bagi pemustaka. Untuk itu kemampuan literasi informasi dan literasi digital bagi pemustaka sangat diperlukan karena kemampuan literasi seseorang menunjukkan kebiasaan menggunakan sumber informasi dan mengaplikasikannya. Begitu juga literasi digital sebagai pemustaka harus bisa membedakan antara informasi berupa fakta atau kebohongan (hoax).

Perpustakaan perguruan tinggi memiliki program literasi informasi dan literasi digital kepada pemustaka yang sedang memanfaatkan 
perpustakaan. Kemampuan pemustaka dalam literasi informasi dan literasi digital dapat digunakann untuk membekali mereka dalam merubah perilaku mencari, memilih, dan menggunakan informasi sebagai sumber rujukan. Perkembangan teknologi yang semakin pesat dan perubahan pola pencarian informasi para pemustaka di era digital ini maka menjadi suatu tantangan bagi para pustakawan dan perpustakaan. Oleh karena itu dalam artikel ini akan dibahas tentang apakah litersi informasi dan literasi digital itu dan apa yang harus dilakukan oleh pustakawan dalam menghadapinya.

\section{Literasi Informasi dan Literasi Digital}

Istilah "information literacy" pertama kali dikemukakan oleh Paul Zurkowski yang mengatakan orang yang literat informasi adalah orang-orang yang terlatih dalam aplikasi sumberdaya dalam pekerjaanna (Behrens,1994). Literasi informasi sering disebut juga dengan kemelekan informasi. Dalam bidang ilmu perpustakaan dan informasi, literasi infromasi sering dikaitkan dengan kemampuan mengakses dan memanfaatkan secara benar informasi yang tersedia. Pengertian literasi informasi yang sering dikutip adalah pengertian literasi informasi dari American Library Association (ALA) : "Serangkaian kemampuan yang dibutuhkan seseorang untuk mengenali kapan informasi dibutuhkan dan memiliki kemampuan untuk menemukan, mengevaluasi, dan menggunakan informasi yang dibutuhkan secara efektif'. Sedangkan pengertian literasi informasi menurut Endang Fatmawati (2010:23) dalam Basuki yaitu: "Sebuah pemahaman dari seperangakat atau serangkaian kemampuan/keterampilan yang dimiliki dan memungkinkan untuk mendapatkan jalan keluar/solusi untuk memecah suatu masalah”.

Dari beberapa pengertian di atas dapat dimaknai bahwa literasi informasi adalah sebuah usaha untuk mendapatkan "kompetensi" guna memecahkan sebuah masalah. Kompetensi merupakan perpaduan antara pengetahuan, kemampuan, dan tingkahlaku. Keterampilan dalam literasi ini mencakup kemampuan dalam mengidentivikasikan masalah, mencari dan menemukan informasi, menyusun, mengorganisir. Perpustakaan dan literasi informasi merupakan dua hal yang saling berhubungan, perpustakaan tanpa bahan perpustakaan dan pustakawan yang memadai tidak akan membantu proses literasi informasi, perpustakaan harus memfasilitasi pemustaka dengan teknologi dan informasi yang mendukung, sehingga membawa dampak positif dan meningkatkan kualitas melek informasi.

Literasi digital merupakan keahlian yang berkaitan dengan penguasaan sumber dan perangkat digital. Literasi digital mencakup pemahaman tentang web dan mesin pencari. Pemustaka memahami bahwa 
tidak semua informasi yang tersedia di web memiliki kualitas yang sama, dengan demikian pemustaka lambat laun dapat mengenali situs web mana yang benar dan situas mana yang tidak dapat dipercayai. Dalam literasi digital ini pemustaka dapat memilih mesin pemakai yang baik untuk kebutuhan informasinya, mampu menggunakan mesin pencara secara efektif.

Menurut Davis \& Shaw ( 2011), istilah literasi digital mulai popular sekitar tahun 2005. Literasi digital bermakna kemampuan untul berhubungan dengan informasi hipertekstual dalam arti bacaan takberurut berbantuan komputer, istilah literasi digital pernah digunakan tahun 1980 an, secara umum bermakna kemampuan untuk berhubungan dengan informasi hipertekstual dalam arti membaca non-sekuensial atau nonurutan berbantuan komputer. Gilster (2007) kemudian memperluas konsep literasi digital sebagai kemampuan memahami dan menggunakan informasi dari berbagai sumber digital, dengan kata lain kemampuan untuk membaca, menulis dan berhubungan dengan informasi dengan menggunakan teknologi dan format yang ada pada masanya.

IFLA ALP Workshop (2006) menyebutkan bagian dari literasi informasi adalah literasi digital, didefinisikan sebagai kemampuan memahami dan menggunakan informasi dalam berbagai format dari sejumlah besar sumber daya tatkala sumber daya tersebut disajikan melalui komputer. Sesusia perkembangan Internet, maka pemustaka tidak tahu atau tidak mempedulikan darimana asalnya informasi, yang penting ialah dapat mengaksesnya.

\section{Wajah Literasi}

Dalam bukunya Tujuh wajah melek informasi Christine Bruce (1997:42) mengidentifikasi tujuh kategori literasi informasi, seperti yang dialami oleh pendidik Australia di dua universitas:

1. Informasi konsepsi teknologi -> menggunakan teknologi informasi untuk pencarian informasi dan komunikasi

2. Sumber-sumber informasi konsepsi -> mencari informasi

3. Proses Informasi konsepsi -> mengeksekusi proses

4. Konsepsi kontrol informasi -> informasi pengendalian

5. Pengetahuan konsepsi konstruksi $->$ membangun basis pengetahuan pribadi di daerah baru yang menarik 
6. Pengetahuan ekstensi konsepsi ->. Bekerja dengan pengetahuan dan perspektif pribadi diadopsi sedemikian rupa sehingga diperoleh wawasan baru.

7. Konsepsi Wisdom -> menggunakan informasi dengan bijak untuk kepentingan orang

Literasi Informasi di dunia akademis sangat penting sehingga peran pustakawan dalam pencapaian misi belajar mengajar di perguruan tinggi menjadi penting. Oleh karena itu munculah upaya melibatkan kolaborasi pustakawan dan dosen untuk memperluas jangkauan pengajaran literasi informasi terhadap mahasiswa, karena program ini tidak cukup sekadar mengandalkan pelayanan referensi di perpustakaan akademis maupun universitas. Pustakawan dapat mengambil peran dalam pengajaran literasi informasi bekerjasama dengan para pendidik, dan literasi informasi perlu menjadi bagian integral dalam kurikulum, karena pembelajaran literasi informasi itu merupakan proses yang berlanjut dan bertahap. Untuk keberhasilan seorang mahasiswa, tidak hanya dalam bangku kuliah, melainkan untuk menerapkan pengetahuan dalam memaknai kehidupan mereka

Literasi informasi berbeda dengan literasi digital. Literasi informasi fokus pada pemahaman kebutuhan informasi seseorang, dilakukan dengan kemampuan untuk menemukan dan menilai informasi yang televan serta menggunakannya secara tepat. Sedangkan literasi digital mencakup pemahaman tentang web dan mesin pencari. Pemakai memahami bahwa tidak semua informasi yang tersedia di web memiliki kualitas yang sama; dengan demikian pemakai lambat laun dapat mengenali situs web mana yang andal dan sahih serta situas mana yang tidak dapat dipercayai. Dalam literasi digital ini pemakai dapat memilih mesin pemakai yang baik untuk kebutuhan informasinya, mampu menggunakan mesin pencara secara efektif (misalnya dengan "advanced search").

Singkatnya literasi digital adalah himpunan sikap, pemahaman, keteramnilan menangani dan mengkomunikasikan informasi dan pengetahuan secara efektif dalam berbagai media dan format. Walaupun literasi digital merupakan hal penting, tidak boleh dilupakan bagian penting lainnya dari literasi digital ialah mengetahui bila menggunakan sumber non digital. Menurut Bawden (2008), komponen literasi digital terdiri dari empat bagian sebagai berikut :

a. Tonggak pendukung berupa literasi itu sendiri dan literasi komputer, informasi, dan teknologi komunikasi. Landasan ini mencerminkan 
ketrampilan tradisional, di dalamnya termasuk literasi komputer yang memungkinkan seseorang mampu berfungsi dalam masyarakat. Menyangkut literasi kompouter, ada pendapat yang mengatakan bahwa literasi komputer merupakan bagian dari literasi digital.

b. Pengetahuan latar belakang terbagi atas dunia informasi dan sifat sumber daya informasi. Pengetahuan latar belakang ini dapat dibagi lebih lanjujut menjadi dunia informasi dan sifat sumber daya informasi. Jenis pendidikan ini dianggap dimiliki oleh orang berpendidikan semasa informasi masih dalam bentuk buku, surat kabar, majalah, majalah akademis, laporan profesional; umumnya diakses melalui bentuk cetak di perpustakaan. Ketika Internet berkembang yang memunculkan dokumen elektronik maka pola komunikasi kepanditan (scholarly communication) atau komunikasi ilmiah (scientific communication) berubah. Bila dulu dikenal model tradisional Garbey/Griffith yang dimulai dari penelitian sampai ke penerbitan yang dilakukan secara tradisional, maka kini mucul Garvey/Griffith yang dimodernisir karena munculnya dokumen elektronik (Crawford, Hurd, \& Weller, 1996)

c. Komptensi berupa : pemahaman format digital dan non digital, penciptaan dan komunikasi informasi digital, evaluasi informasi, perakitan engetahuan, literasi informasi, dan literasi media. (Davis \& Shaw, 2011). Kesemuanya itu merupakan ketrampilan dan kompetensi yang merupakan landasan literasi digital. Ketramnpilan dan kompetensi tersebut memiliki jangkauan luas dan mungkin berbeda antara satu negara dengan negara lain.

d. Sikap dan perspektif merupakan hal yang, menciptakan tautan antara konsep baru literasi digital dengan gagasan lama tentang literasi. Perseorangan tidak cukup memiliki ketrampilan dan kompetensi melainkan hal itu harus berlandaskan kerangka kerja moral,yang diasosiasikan dengan seseorang yang terdirik. Dari semua komponen literasi digital, mungkin yang paling sulit diajarkan adalah kerangka kerja moral, namun hal itu paling kuat kedekatannya dengan istilah informasi dalam akar bahasa latinnya informare artinya membentuk, memaparkan.

\section{Sikap Pustakawan}

\section{Bagaimana Sikap Pustakawan dalam Literasi digital}


Urgensi pustakawan dalam literasi digital yang pertama adalah menjadi pustakawan yang melek informasi. Karena melek informasi adalah karakteristik seorang pustakawan, maka dapat dicoba untuk memulai program literasi informasi bagi pemustaka. Seperti misalnya: melayani layanan rujukan, menolong pemustaka yang kelihatan bingung, menjelaskan tentang perpustakaan kepada pemustaka tamu, diskusi internal atau pribadi dengan rekan, bincang santai dengan mahasiswa magang yang ada di perpustakaan.

Hal-hal seperti tersebut diatas dapat digunakan untuk membagikan tentang literasi informasi digital. Apabila pustakawan akan memulai suatu program literasi yang serius dalam perpustakaan, berikut beberapa langkah sederhana untuk memulai program tersebut :

a. Observasi kesempatan, fasilitas, dan wewenang. Perhatikan apa saja yang dimiliki perpustakaan, sarana dan prasarananya, SDM, SDI, alat, kesempatan, relasi, serta wewenang untuk membuat program literasi informasi. Analisis segala kemungkinan yang ada bersumber dari evaluasi profil pemustaka tadi.

b. Tentukan target, dari sekian banyak jenis kebutuhan informasi pemustaka, tentukan mana yang paling mungkin untuk dilaksanakan. Pilihan model informasi yang paling dipahami sangat berpengaruh terhadap berlangsungnya kegiatan perpustakaan. Dalam menentukan model literasi informasi harus memperhatikan : materi yang diberikan, kemampuan yang dituju dan bentuk penyampaian serta bentuk program.

c. Merancang, lakukan studi banding melalui website perpustakaanperpustakaan yang ada di dunia. Konsultasikan dengan orang yang pernah melakukan program tersebut. Buatlah proposal program yang berisi latar belakang, tujuan, target, materi, bentuk program, kebutuhan yang diperlukan, SDM dan hal lainnya yang menjelaskan tentang program.

d. Laksanakan dan lakukan evaluasi. Sangat menjadi kebangga tersendiri memiliki kesempatan menjalankan program literasi informasi sehingga dapat merasakan bagaimana mengajar dan memberdayakan orang lain. Berbagilah tentang pengetahuan literasi informasi dengan pemustaka melalui media internet juga. Gunakan situs perpustakaan, gubakan blog pribadi, facebook, twitter dan lainlain yang dapat dijangkau oleh pemustaka. (Emi Tri Mulyani, http://digilib.isi-ska.ac.id/?p=639) 


\section{Peran Pustakawan Dalam Literasi Digital}

Literasi informasi menjadi sebuah ketrampilan pustakawan yang penting di era digital saat ini, karena sudah seharusnya penguasaan literasi informasi menjadi bagian yang tak terpisahkan dari pustakawan. Pustakawan harus menjadi manajer ilmu pengetahuan, karena setiap harinya berkecimpung dengan berbagai sumber informasi. Menyikapi hal ini, maka mau tidak mau pustakawan harus bisa menelusur informasi di perpustakaan baik secara manual maupun online. Pustakawan perlu memahami fisi dan misi fakultas, berbagi jargon, definisi, terminology teknis, kerelaan untuk mempelajari aspek-aspek dari kepiawaian sejawat, dan kemampuan untuk menghargai perbedaan dan tidak mingkirik atau menyamaratakan profesional lain. Barangkali kolaborasi akan berhasil jika masing-masing pihak: menyamakan tujuan, saling menghargai, bertoleransi dan saling percaya, kompetensi untuk menjalankan tugas masing masing, dan komunikasi

Konsep Bell dan Shank (2004) dalam Abdul Karim Batubara tentang "Blended Librarian" dapat diterapkan. Blended Librarian (secara harafiah berarti pustakawan terpadu). Mereka definisikan sebagai pustakawan akademis yang menggabungkan sejumlah ketrampilan kepustakawanan tradisional dengan ketrampilan perangkat lunak dan perangkat keras dan perancang bimbingan atau pendidikan untuk menerapkan teknologi secara tepat untuk proses belajar mengajar. Sebagai mitra di kelas, pustakawan terpadu terlibat dalam melaksanakan kolaborasi dan integrasi literasi dalam proses belajar mengajar. Oleh karena itu, idealnya pustakawan tetap memasukkan misi mengajar universitas dengan basis kuliah. Selanjutnya pustakawan perlu membuktikan posisi mereka dalam struktur kurikulum universitas, dan seperti yang dikatakan Bell dan Sank dalam artikel mereka "Blended Librarian" dan ini bisa terjadi bila pustakawan memahami pedagogi dan menggunakan prinsip rancangan instruksional, teori dan praktek.

Pelayanan referensi dan pengajaran literasi informasi telah ditransformasikan oleh kemajuan teknologi, perubahan sosial dan perkembangan pendidikan. Meja referensi mendapatkan mobilitas dan ada dimana mana, menjangkau pemustaka di daerah baru, baik

secara fisik maupun maya. Pada tingkat operasi, peran profesional dan para profesional telah berubah, dengan praktisi spesialis diharapkan menunjukkan tingkat spesialisasi yang tinggi muncul untuk dunia digital dimana batasan lintas fungsi. Riset menunjukkan bahwa peran pengajaran di pelayanan referensi diakui secara universal dan tetap mengutamakan tatap muka dan 
transaksi referensi digital, tetapi sering tidak dinyatkan dalam kebijakan dan rencana formal, terutama yang berkaitan dengan prioritas. Padahal ini memberi kemudahan belajar sepanjang hayat dalam masyarakat. Karena bimbingan literasi informasi cukup kompleks, perlu melibatkan profesional.

\section{Peluang dan Tantangan Pustakawan}

Pustakawan merupakan sebuah profess dalam menyediakan informasi terutama dalam bentuk digital kepada pemustaka. Peluang berarti kesempatan sedangkan tantangan adalah hal atau obyek yang menggugah tekat untuk meningkatkan kemampuan, untuk mengatasi masalah, memotivasi untuk bekerja lebih giat lagi.

ada dua hal yang harus dikembangkan untuk menghadapi tantangan era digital saat ini yaitu:

a. Kompeten profesi, selaku pustakawan adalah meningkatkan pengetahuan yang dimiliki pustakawan dalam bidang sumber daya informasi, akses informasi, teknologi informasi, manajemen dan riset serta kemampuan untuk menggunakan pengetahuan tersebut sebagai dasar untuk menyediakan layanan literasi informasi digital.

b. Kompetensi personal yaitu keterampilan, keahlian, sikap dan nilai yang memungkinkan pustakawan bekerja secara efesien, menjadi komunikator yang baik, selalu meningkatkan pengetahuan, dapat menunjukan nilai lebih serta bertahan dalam perubahan dan perkembangan dunia kerja (Djuwarnik, 2013)

Selain itu yang dipersiapkan dan dikembangkan oleh pustakawan adalah melakukan strategi, pendekatan promosi, advokasi (lobi dan negosiasi) kepada pimpinan instansi untuk mendukung adanya literasi informasi digital dengan membuat serangkaian program seperti edukasi ke pemustaka dengan memasukan literasi informasi digital sebagain program pengembangan layanan perpustakaan.

Literasi digital berdampak pada pustakawan karena dia harus menguasai literasi informasi serta literasi lainnya sehingga memungkinkan pustakawan mengembangkan kegiatan literasi informasi di lingkungannya. Pengetahuan latar belakang juga menimbulkan masalah pada pendidikan pustakawan. Apakah pola pendidikan pustakwan yang didominasi program sarjana masih diteruskan atau diubah? Pengalaman menunjukkan bahwa pustakawan yang berbasis sarjana ilmu perpustakaan merasakan kurang bekal ilmu pengetahuan lain ilmu perpustakaan untuk kepentingan pekerjaannya. Maka banyak pustakwan yang bergelar sarjana ilmu perpustakaan, manakala 
sudah bekerja, melanjutkan pendidikan di tingkat pascasarjana bidang lain seperti komunikasi, pendidikan, sejarah dan lain-lain. Keadaan semacam itu mencetuskan gagasan mengapa beberapa lembaga penyelenggara pendidikan pustakawan lebih memusatkan pada pendidikan pascasarajana disertai dengan kegiatan riset sedangkan lembaga lain tetap berkonsentrasi pada program arjana saja.

\section{Peran Perpustakaan Nasional dalam Pengembangan Literasi Informasi}

Perpustakaan Nasional RI sebagai lembaga pemerintah nondepartemen, merupakan kepanjangan tangan dari pemerintah untuk melaksanakan amanat konstitusi, termasuk juga amanat untuk mengembangkan literasi informasi di masyarakat. Untuk itu diperlukan pemahaman diri karena pemahaman ini menjadi dasar dari seluruh kegiatan yang dilakukan.

\section{Program dan Kebijakan Literasi Informasi}

Tujuan perpustakaan dapat disarikan dalam dua kegiataan utama yaitu kegiatan pelestarian dan kegiatan pendidikan. Literasi informasi terkait erat dengan kegiatan pendidikan. Kegiatan pendidikan dilakukan sebagai pengakuan negara akan hak-hak asasi manusia, termasuk hak literasi informasi yang telah diakui oleh konstitusi. Dalam hal literasi informasi, ada beberapa program dan kebijakan yang sudah dilakukan oleh Perpustakaan Nasional RI antara lain:

- Literasi informasi i telah menjadi bagian dalam Rencana Induk Perpustakaan Nasional tahun 2006-2015.

- Lomba-lomba Penulisan. Lomba penulisan adalah sarana pendidikan literasi informasi yang sangat efektif. Lomba nasional penulisan artikel tentang Perpustakaan Nasional RI mempunyai dua keuntungan yaitu pertama Perpustakaan Nasional akan mendapat masukkan dari para pemerhati perpustakaan, yang kedua secara tidak langsung mendidik literasi informasi bagi para pesertanya.

- Kampanye dan penggerakan minat baca di masyarakat.

- Peresmian layanan perpustakaan keliling dilengkapi dengan teknologi informasi

- Pemanfaatan teknologi informasi dalam tata laksana pekerjaan.

- Pemanfaatan teknologi informasi sebagai sarana komunikasi dengan masyarakat 
- Pengembangan website http://www.pnri.go.id dan penyediaan database koleksi online

- Pelatihan, seminar dan kajian-kajian mengenai literasi informasi.

- Dukungan untuk organisasi-organisasi literasi informasi

- Melakukan berbagai pembinaan-pembinaan terkait dengan literasi informasi

○ Identifikasi potensi-potensi untuk pengembangan literasi informasi

\section{Potensi-potensi untuk Pengembangan Literasi Informasi}

Potensi pada dasarnya adalah sebuah kekuatan yang ada tapi tidak disadari atau belum secara optimal dimanfaatkan

a. Potensi Kewenangan

Kedudukan Perpustakaan Nasional sebagai lembaga pemerintah nondepartemen, memungkinkan untuk menyusun berbagai peraturan dan perundang-undangan sesuai dengan kewenangannya. Kewenangan ini sebaiknya dimanfaatkan secara optimal untuk mengkaji dan menyusun peraturan dan perundangan yang berlaku dalam rangka pengembangan literasi informasi.

\section{b. Potensi Sumber Daya Manusia}

Pada dasarnya pustawakan adalah pekerja informasi yang menyediakan informasi bagi yang membutuhkannya. Tugas pekerja informasi adalah mengetahui seluk beluk informasi, mengetahui lokasi, pintar menganalisis dan memberikan informasi yang tepat kepada yang membutuhkannya. Untuk itu pustakawan harus mempunya kemampuan literasi informasi dan sanggup melatih kemampuan ini untuk orang lain. Perpustakaan Nasional RI diharapkan dapat mengembangkan literasi informasi informasi bagi pustakawan dengan menyediakan berbagai pelatihan dan sarana untuk berkembang.

\section{c. Potensi Teknologi Informasi dan Komunikasi}

Teknologi informasi dan komunikasi dapat dikategorikan sebagai sarana untuk melakukan literasi informasi. Teknologi informasi akan semakin dirasakan manfaatnya pada saat ini terlebih di masa yang akan datang. Salah satu teknologi informasi yang sangat pesat perkembangannya adalah Internet. Jaringan global Internet memungkinkan data dan informasi dari berbagai penjuru dunia dapat dengan cepat diperoleh. Teknologi 
Informasi dan komunikasi harus dimanfaatkan secara maksimal oleh Perpustakaan Nasional RI untuk pengembangan literasi informasi.

\section{d. Potensi Komunitas Informasi dan Pengetahuan}

Di belakang teknologi informasi dan komunikasi yang menggerakannya adalah komunitas Informasi. Komunitas ini aktif menggunakan teknologi informasi dan memanfaatkannya untuk pengembangan diri dan lingkungan sosialnya. Sebagai contoh diantaranya adalah: proyek Gutenberg yang berusaha menyediakan $e$-book public domain Perpustakaan Nasional sebaiknya menjalin kerja sama erat dengan komunitas informasi untuk mengembangkan literasi informasi.

\section{e. Potensi Kerjasama}

Kegiatan besar ini akan terasa berat jika dilaksanakan sendiri, oleh karena itu Perpustakaan Nasional perlu menjalin kerjasama dengan pihak lain yang mempunyai tujuan yang sama. Kerjasama dapat dilakukan dengan departemen terkait, LSM, praktisi, perusahan-perusahaan nasional dan multinasional. Untuk kerjasama dengan perusahaan dilakukan dalam rangka menjalankan Corporate Social Responsibilities. Khusus untuk perusahaan telekomunikasi juga terdapat kewajiban Universal Service Obligation yang dapat diarahkan untuk mengembangkan literasi Informasi. (Dwiyanto, 2007)

\section{Kesimpulan}

Literasi informasi dan literasi digital mencakup pengetahuan dan kebutuhan informasi seseorang dan kemampuan untuk mengenali, mengetahui lokasi, mengevaluasi, mengorganisasi danmenciptakan, menciptakan dan mengkomunikasikan informasi secara efektif untuk mengatasi isu atau masalah yang dihadapi seseorang. Saat ini pustakawan dituntut tidak hanya trampil mengurusi buku atau jenis mediainformasi lain. Namun dituntut bisa menguasai penelusuran literasi informasi dan litersi digital yang menjadi sebuah terobosan baru dan tantangan ke depan bagi pustakawan dalam mengemban tugas mulia untuk mengelola informasi yang ada di perpustakaan. Dengan demikian, pustakawan harus mempunyai komitmen dengan penuh kesadaran agar dapat mengakses, memahami dan memanfaatkan informasi yang diperoleh untuk dikomunikasikan kepada masyarakat (pemustaka) yang membutuhkan.

\section{Daftar Rujukan}


Batu Bara, Abdul Karim. 2014 , Literasi informasi di perpustakaan. Jurnal Iqra' vol. 08 no.01 Mei, 2014 hlm. 17

Bawden, D. 2008. Origins and concepts of digital literacy. Dalam C. Lankshear\&M. Knobel

(eds). Digital literacies : concepts, policies, and paradoxes. Pp:15-32. New Yok: Peter

Lang

Behrens, S. 1994. A conceptual analysis and historical review of information

literacy. College and Research Libraries, 55,309-322

Bruce, Chirtine. 1997. The seven faces of information literacy. Adelaide:Auslib Press

Crawford,Susan Y.; Hurd,Julie M. and Weller, Ann C. (1996). From p[rint to electronic: the

transformation of scientific communication. Medford,NJ:Information Today.

Davis, Charles H.; Shaw,Debora (eds). 2011. Introduction to information science

and technology. Medford,NJ: Information Today

Djuwarnik, 2013. Meningkatkan profesionalisme pustakawan di tengah perkembangan meningkatkan

teknologi informasi. Prosiding:peran jejaring perpustakaan dalam

kompetensi pustakawan hlm. 3

Dwiyanto, Arif Rifai. 2007. Peran Perpustakaan Nasional RI dalam mengembangkan literasi

Desember

informasi sebagai amanat konstitusi, Visi Pustaka vol.9 no.3

Fatmawati, Endang. 2010. The Art Of Library : Ikatan Esai Bergizi Tentang Seni Mengolah

Perpustakaan.Semarang: Badan Penerbit Universitas Diponegoro

Gilster, P. 1997. Digital literacy. New York:Wiley 
102 | Daryono: Literasi Informasi Digital ...

IFLA ALP Woorkshop on Information Literacy and IT, Auckland,New Zealand. (2006). The

basic information literacy skills.

Wulansari, Ayu. 2017. Information literacy: peluang dan tantangan pustakawan di era

digital native. Prosiding: Semiloka Kepustakawanan Indonesia2016, 12-14 Oktober

2016, Yogyakarta: Gajah Mada University

http://crln.acrl.org/content/65/7/372.full.pdf

http://digilib.isi-ska.ac.id/?p=639

https://sulistyobasuki.wordpress.com/2013/03/25/literasi-informasi-danliterasi-digital/

http://media.wiley.com/product_data/excerpt/78/07879652/0787965278.pdf 